\title{
О важности языковой политики
}

\author{
Елена Вартанова
}

Более двух с половиной столетий назад создатель первого университета в России, автор «Российской грамматики» Михаил Васильевич Ломоносов ввел родной язык в академическое сообщество, придав ему высочайший статус языка науки и культуры. Именно в стенах Московского университета на факультете журналистики прошел лингвострановедческий семинар «Языковая политика во Франции и в России: проблемы и перспективы», организованный под эгидой российско-французского форума гражданских обществ «Трианонский диалог» в сотрудничестве с Федеральным агентством по печати и массовым коммуникациям, Министерством просвещения России и Министерством культуры Франции. И хотя семинар состоялся в 2019 году, его материалы оказались ценными и актуальными и для 2020 года, поэтому мы решили большую часть очередного номера журнала «Медиа@льманах» посвятить теме семинара.

На семинаре обсуждались такие вопросы, как выработка методов и механизмов для развития и продвижения национального языка, проблемы культуры речи, правовые и институциональные аспекты языковой политики в России и во Франции и другие темы, актуальные для языковой среды государства. В российско-французском мероприятии приняли участие авторитетные ученые и государственные деятели двух стран, чья деятельность напрямую связана с защитой и развитием родных языков, формированием государственной политики в этой сфере. Двухдневный семинар открыл председатель Совета по русскому языку при Президенте РФ, президент Международной ассоциации преподавателей русского языка и литературы В.И. Толстой.

Сегодня в связи с возросшим влиянием открытого публичного медиапространства на жизнь людей, с важностью безопасного и эффективного использования традиционных СМИ и социальных медиа культурно-речевые явления становятся важным компонентом не только культурного, но и политического процессов, влияют на медиаэкологию современного общества и глобального мира, определяют цифровой информационный капитал личности. Человеку сегодня необходимо критически оценивать 
не только смыслы того, что он находит в медиапространстве, но и языковые формы, в которые эти смыслы облечены, их соответствие национальной традиции использования речи.

Грамматическая и стилистическая безграмотность, просторечная и обсценная лексика, иноязычные заимствования становятся угрозами культуре речи. Цифровая эпоха, в которой мы живем, в условиях безграничной медиасреды позволяет аудитории получить беспрепятственный доступ к самым разным текстам. И рядом с текстами журналистов присутствуют «на равных» рекламные и пиар-тексты, сообщения пользователей всевозможных онлайн-сообществ, высказывания и реплики непрофессиональных авторов... Все чаще такая информационная избыточность характеризуется нарушением не только языковых, но и лингвоэтических норм, речевой агрессией. Активная аудитория, становясь сама производителем медийного текста, может привносить нетипичную для публичной сферы злобу, некорректность, прямые оскорбления, сквернословие. И это становится проблемой публичной медиакоммуникации, в которой традиционно принято соблюдать не только требования закона, но и неписаные правила, культурные нормы и лингвоэтический кодекс.

Наряду с необходимостью борьбы за лингвоэкологию речи СМИ и социальных медиа языки во многих странах мира испытывают угрозы деструктивного воздействия со стороны определенных, возможно даже коммерчески детерминированных разновидностей английского языка или языка массовой культуры, или глобально усредненного и упрощенного до 1500 слов варианта английского (Globish от global и English). Речь идет о защите родного языка как основы культурной и национальной идентичности страны. Именно этому аспекту языковой политики уделяется все больше внимания по всему миру. Пример Франции в связи с этим весьма показателен: страна выработала специальную стратегию для поддержки и защиты родного языка внутри страны и на международной арене. Россия также выступает с позиции развития и продвижения русского языка и помогает включаться в образование на русском языке независимо от мест проживания - как соотечественников, так и всех желающих. Политика обеих стран направлена на выработку гибкого и устойчивого механизма, который поможет сохранить богатство, накопленное нашими языками.

Сохранение и развитие русского языка как государственного языка РФ, родного для подавляющего большинства граждан нашей страны, обеспечивается профильными ведомствами, органами власти, системой образования, учреждениями и деятелями культуры. При этом цель и характер языковой политики в России определяет ее многонациональность и право каждого народа на сохранение и изучение родного языка.

Франкофонная языковая среда, в отличие от русской языковой среды, давно существует в пределах границ разных национальных государств. Французам удается это благодаря эффективной политике сохранения и продвижения языка: приняты такие меры, как отслеживание языковой девиации во франкоязычных странах, активное развитие переводческой 
школы и регулирование профессионального языка, в том числе выпуск словарей с профессиональной лексикой (например, электронный словарь франкофонов, вышедший во Франции в 2020 году, содержиттриста тысяч слов, включая региональные диалекты). В определенных аспектах опыт Франции может быть весьма полезен и для России.

Государственную политику невозможно верно определять, если заниматься только фиксированием словоупотребления. Важно анализировать культуру речи в общественном пространстве, и решать эту задачу следует совместными усилиями академических и образовательных учреждений. Исследователи должны не только проводить регулярный мониторинг языка СМИ, как это делает факультет журналистики МГУ имени М.В. Ломоносова, но и, опираясь на опыт французских коллег, формировать ежегодный доклад о состоянии языка и предоставлять его широкой общественности. Обсуждение таких докладов будет способствовать распространению языковой нормы и привлечет внимание общественности к вопросам культуры речи.

Для такой большой и мультикультурной страны, как Россия, русский язык как основа общего информационного пространства является не только пространством гражданской и профессиональной коммуникации, но и универсальной культурной средой, формирующей и укрепляющей национальную идентичность. Сегодня особенно актуально обращение к вопросам культуры речи и представителей государственной власти, и академического сообщества, и профессионалов медийной сферы. Прошедший на факультете журналистики МГУ семинар - успешный опыт такого сотрудничества. 